IZA DP No. 4931

The Employment Effects of Low-Wage Subsidies

Kristiina Huttunen

Jukka Pirttilä

Roope Uusitalo

May 2010 


\title{
The Employment Effects of Low-Wage Subsidies
}

\author{
Kristiina Huttunen \\ Labour Institute for Economic Research \\ Jukka Pirttilä \\ University of Tampere \\ and Labour Institute for Economic Research \\ Roope Uusitalo \\ Government Institute for Economic Research, \\ IFAU and IZA
}
Discussion Paper No. 4931
May 2010

IZA

P.O. Box 7240

53072 Bonn

Germany

Phone: +49-228-3894-0

Fax: +49-228-3894-180

E-mail: iza@iza.org

\begin{abstract}
Any opinions expressed here are those of the author(s) and not those of IZA. Research published in this series may include views on policy, but the institute itself takes no institutional policy positions.

The Institute for the Study of Labor (IZA) in Bonn is a local and virtual international research center and a place of communication between science, politics and business. IZA is an independent nonprofit organization supported by Deutsche Post Foundation. The center is associated with the University of Bonn and offers a stimulating research environment through its international network, workshops and conferences, data service, project support, research visits and doctoral program. IZA engages in (i) original and internationally competitive research in all fields of labor economics, (ii) development of policy concepts, and (iii) dissemination of research results and concepts to the interested public.
\end{abstract}

IZA Discussion Papers often represent preliminary work and are circulated to encourage discussion. Citation of such a paper should account for its provisional character. A revised version may be available directly from the author. 
IZA Discussion Paper No. 4931

May 2010

\section{ABSTRACT}

\section{The Employment Effects of Low-Wage Subsidies ${ }^{*}$}

Low-wage subsidies are often proposed as a solution to the unemployment problem among the low skilled. Yet the empirical evidence on the effects of low-wage subsidies is surprisingly scarce. This paper examines the employment effects of a Finnish payroll tax subsidy scheme, which is targeted at the employers of older, full-time, low-wage workers. The system's clear eligibility criteria open up an opportunity for a reliable estimation of the causal impacts of the subsidy, using a difference-in-difference-in-differences approach. Our results indicate that the subsidy system had no effects on the employment rate. However, it appears to have increased the probability of part-time workers obtaining full-time employment.

JEL Classification: H24, J23, J68

Keywords: low-wage subsidies, employment, social security contributions

Corresponding author:

Jukka Pirttilä

Department of Economics

33014 University of Tampere

Finland

E-mail: jukka.pirttila@uta.fi

\footnotetext{
* We are grateful to Matz Dahlberg, Tomi Kyyrä and seminar participants at MIT, the Athens University of Economics and Business, the Helsinki Centre for Economic Research, the CESifo Area Conference on Labour Economics, the University of Jyväskylä, and the 2009 EALE Conference (Amsterdam), the Nordic Summer Institute in Labour Economics (Aarhus), and the Nordic Seminar for Public Economics (Uppsala, Sweden) for useful comments. Kari Eerola provided excellent research assistance and Ossi Korkeamäki helped with calculations involving the FLEED data. Financial support from the Finnish Employees' Foundation is gratefully acknowledged.
} 


\section{Introduction}

One way to reduce unemployment among the low skilled is to cut labour taxation for lowincome workers. The basic idea in targeted tax cut is that it decreases the cost of employing the target-group workers, and thus increases wages and employment of this group. In theory it should not matter whether tax cuts are provided as a wage subsidy to the employers or as an equivalent income tax reduction to the workers. However, in practice, the wage subsidy given to the employers of low-skilled workers can be more effective in increasing the demand for those workers than a reduction in the taxes paid by the employees. ${ }^{1}$ The reason is that if wages are rigid downwards, the subsidy reduces labour costs and therefore increases labour demand more than a reduction in the labour income tax paid by the employees themselves.

Despite the large agreement in the theoretical literature that these subsidies should be effective, there is relatively little empirical research that has examined the effectiveness of the (employer-side) wage subsidies. This is in a marked contrast to a large literature that has examined the effects of the targeted tax cuts for employees. ${ }^{2} 3$ One reason for the lack of research is that low-wage subsidies, in the form of targeted cuts to employers' social security contributions, have not been implemented in practice in many countries.

The purpose of this paper is to offer new evidence on the causal effects of low-wage subsidies by examining the impacts of a highly targeted low-wage subsidy experiment that started in Finland in 2006. The design of the Finnish low-wage subsidy scheme makes evaluating its impacts relatively straightforward. In order to be eligible for the subsidy, the workers must be over 54 years of age, earn a salary between 900 and 2,000 euros per month and work full time. This means that we can find several comparison groups for the targeted workers, thus allowing a difference-in-difference-in-differences (DDD) approach. We can simultaneously control for any permanent differences across the eligible and ineligible groups and take into account time-varying differences in labour demand for different skill groups. The latter, particularly, may be quite important if skill-biased technical change or globalisation changes the relative productivity of different workers.

\footnotetext{
${ }^{1}$ See Phelps (1994, 1997) and Dreze and Malinvaud (1994)

${ }^{2}$ See Eissa and Liebman (1996) and Eissa and Hoynes (2004) who examine the effects of the Earned Income Tax Credit in the US case and Blundell et al. 2006 for the UK evidence on the effectveness of Working Families Tax Credit (WFTC) or Card and Hyslop (2005) for experimental evidence on effectiveness of Self Suffiency Project.

${ }^{3}$ There is also large literature which focused on hiring subsidies that are directed to unemployed workers.
} 
The empirical analysis in the paper has many phases and utilises several different data sets. We begin by looking at the overall impacts of the subsidy system on the employment rates using data from the Finnish Labour Force Survey. In the following part we use register data of the unemployed and examine in detail whether the subsidy system increased re-employment rates of the unemployed. In the last part we use data that cover all workers in firms that are members of the Finnish Employers' Confederation. The benefit of these data is that they contain detailed information about the working hours and monthly wages of the workers that determine eligibility for the subsidy. This enables us to build a clearly defined treatment group and corresponding control. We examine the impacts of the subsidy system on the job leaving rate, as well as working hours and wages of those workers who keep their jobs.

This paper contributes to the literature in many ways. First, as mentioned already, the clear eligibility criteria of the Finnish low-wage subsidy experiment makes it possible to examine the effects of a low-wage subsidy on target-group employment, while controlling for the simultaneous changes that affect the demand for all low-wage worker or all older workers. Second, this paper adds to the relatively scarce literature that has examined the effects of lowwage subsidies on employment and it is the first that uses data from a Nordic country. Finland is a good case for analysing the effectiveness of payroll tax subsidies. Union contracts have led to a relatively narrow wage distribution which could have contributed to the gap in the unemployment rates between low-skilled and high-skilled workers that is among the largest in Europe, according to the Eurostat Labour Force Survey. Finally, since the subsidy scheme was targeted to older workers, our results also provide new evidence on the effectiveness of policies that aim to increase the demand for older workers.

The paper proceeds as follows. Section 2 reviews earlier relevant empirical work. ${ }^{4}$ Section 3 explains the Finnish subsidy system in more detail. In section 4 we look at the trends in the employment rates of workers in different age groups using data from the Finnish Labour Force Survey. In section 5, we use register-data of the unemployed and examine in detail whether the subsidy system affected re-employment rates of unemployed. In Section 6 we examine the impacts of the subsidy system on the job leaving rate, as well as working hours and wages of those workers who keep their jobs using data of the Finnish Employers' Confederation. Finally, section 7 discusses results from a number of extensions to the analysis above. Section 8 concludes.

\footnotetext{
${ }^{4}$ For the sake of space, we do not cover the theoretical literature on payroll tax subsidies here. Brown et al. (2007) contains an extensive list of theoretical work in the area.
} 


\section{Earlier empirical work}

The best-known scheme aiming at promoting low-wage employment with subsidies to employers was implemented in France, where payroll taxes were reduced for the low-wage workers several times in mid 1990's. The main difference between the Finnish and the French subsidy schemes is that the French subsidy affects all low-wage workers, while the Finnish subsidy is targeted at older low-wage workers. The evaluation of French scheme is thus more difficult, since it is hard to distinguish between the employment effects that are due to the subsidy from the simultaneous changes affecting all low-wage workers ${ }^{5}$.

Employment effects of the French payroll tax subsidy scheme have been evaluated by Kramarz and Philippon (2001) and Crepon and Desplatz (2003). Kramarz and Philippon base their evaluation on household survey data and examine the effects of changes in the minimum labour costs - hence capturing the effects of both the changes in minimum wage and the changes in payroll tax subsidies at the minimum wage level. By comparing workers affected by the minimum wage increases with workers just above the new minimum wage, they show that increases in labour costs increase transitions to non-employment. However, their analysis regarding the effects of a decrease in the labour costs due to an increase in the payroll tax subsidy reveals no significant employment effects. The authors measure this as an increase in minimum-wage workers coming from non-employment.

Crepon and Desplatz (2003) perform their analysis with firm-level employment as the key dependent variable. They calculate the ex-ante change in labour costs due to the payroll tax subsidies, using payroll tax parameters and the composition of the firm's labour force before the introduction of the payroll tax changes. They find that employment in firms that received larger subsidies grew more than employment in firms that employed fewer low-wage workers and hence received fewer subsidies. The authors interpret this as strong evidence for the employment effects of low-wage subsidies. Since the outcome variable is total employment, the authors cannot discover whether the increase in employment occurs in the targeted lowwage group or whether the increase in employment is due to an increase in high-wage workers.

\footnotetext{
${ }^{5}$ The Finnish and French subsidy systems are roughly similar in magnitude, but the Finnish subsidy is phased out more slowly and hence has an impact on labour costs at much higher wage levels.
} 
Targeted payroll tax subsidies have also existed in the Netherlands and in Belgium. Goos and Konings (2007) evaluate the effects of changes occurring in the 'Maribel subsidies' system in Belgium in the late 1990s using firm-level data. These subsidies reduced the payroll taxes paid on manual workers. Even though the subsidy was not specifically targeted to the employers of low-wage workers, its lump-sum structure reduced the payroll taxes for the lowwage workers more than for the other groups. Goos and Konings find that the subsidy had significant effects on employment ${ }^{6}$.

The subsidies discussed above involve a decrease in the payroll taxes of the subsidized workers. Gruber (1994) analyses the effect of a reverse experiment, increasing the costs of hiring certain groups by increasing mandatory employer contributions. He examines the effects of forcing employers to purchase health insurance that includes maternity benefits, a change mainly affecting young women. He shows that the costs of these group-specific mandates are mainly borne by workers in terms of lower wages and that the additional costs have little effects on employment.

While permanent non-categorical subsidies to all employers of the low-wage workers are rather rare, there is a large literature evaluating the effects of temporary subsidies to employers who hire long-term unemployed persons or workers with disabilities. Many of these programs have been evaluated using randomised trials. In his comprehensive survey of the US programs Katz (1996) concludes that wage subsidies have been effective in improving the earnings and employment of disadvantaged groups, at least when combined with training elements. More recent evidence is available from Britain, where the so-called 'New Deal' system has led to modest improvements in the productivity of the target group (e.g. Blundell et al. 2004). ${ }^{78}$

As discussed in the introduction, an alternative to employer-based subsidies is to target the subsidy to employees. This is the way in which the Earned Income Tax Credit in the US and the Working Families Tax Credit in the UK are designed. There exits a large literature that

\footnotetext{
${ }^{6}$ We are not aware of the econometric evaluations of the Dutch system, but Bovenberg et al. (2000) evaluate its effects using a simulation model calibrated to Dutch data. Their conclusion is that the most effective way of reducing unemployment is the introduction of in-work benefits, though the simulation results between the benefits paid to the low-wage workers or to the employers of these workers are roughly similar.

${ }^{7}$ See also Gesine (2009) that focuses on the wage effects of hiring subsidies. His paper also includes an extensive survey of the empirical work on hiring subsidies.

${ }^{8}$ There is also literature on the effects of payroll tax reductions that affected all employees (Gruber, 1997), or all employees in some regions (Korkeamäki and Uusitalo, 2009 and Bennmarker et al., 2009).
} 
examines the effectiveness of employee-base subsidies. Despite the different nominal recipients, there are also similarities that make the results from the evaluation of these subsidy schemes relevant for the Finnish case. All these schemes share the property that the subsidy is targeted to the low-wage workers and that the subsidy gradually decreases after earnings increase above some threshold level. They are also intended to be permanent subsidies for the low-wage workers instead of temporary subsidies for the newly hired. Importantly for the evaluation, these schemes also have other eligibility criteria in addition to low earnings. This allows comparing wage and employment changes after the introduction or expansion of the subsidy in the eligible group and in some comparison group that is in a reasonably similar position in the labour market. Using this strategy, Eissa and Liebman (1996) and Blundell (2006) compare the changes in labour supply between single mothers and (ineligible) single women without children. Both of these studies find substantial effects on the labour supply ${ }^{9}$.

\section{The Finnish employer low-wage subsidy scheme}

Since January $1^{\text {st }} 2006$ Finnish employers have been eligible for a wage subsidy if they employ a low-wage worker that is over 54 years old. The subsidy-scheme is temporary and will be in force until December 2010. ${ }^{10}$ The subsidy depends on the wage level and may be up to 16 per cent of the gross wage or 13 per cent of the total pre-reform labour costs including payroll taxes.

The subsidy covers full-time workers who are employed at least 140 hours per month and whose wage is between 900 and 2,000 euros per month. The subsidy equals 44 per cent of the part of the monthly wages that exceeds 900 euros. The maximum subsidy per employee is 220 euros a month. The amount of the subsidy is reduced by 55 per cent of the monthly wages exceeding 1,600 euros.

The wage subsidy is paid to the employer and can be seen as simply a reduction in the payroll tax rate for the firms that employ old low-wage workers. In 2006 the average payroll tax rate

\footnotetext{
${ }^{9}$ Card and Hyslop (2005) provide experimental evidence on the effectiveness employee-based wage subsidies. They evaluate Canadian Self-Sufficiency Project, which gave randomly chosen welfare recipients a subsidy for full-time work for 3 years. The results indicate that the subsidy had a clear negative- although temporary- effect on welfare participation.

${ }^{10}$ Whether the system will be continued will depend on its effectiveness during the experimental period. Since the experiment will be quite long, it is reasonable to believe that firms can react to it and therefore the evaluation of this system will also reveal relevant information for a truly permanent scheme.
} 
was 20.9 per cent of the gross wage. The tax is levied on all wages. The revenues are mainly used for funding the employee's pension system and the sickness insurance. The tax rate is slightly higher for larger and more capital-intensive firms. For large firms, pension payments also vary according to the age structure of the employees and according to the disability and unemployment pensions granted to former employees. Still, even for large firms the payroll tax is a proportional tax on all wages paid.

The 2006 tax subsidy created a system where the payroll tax rate is a decreasing function of monthly wages when wages are between 900 and 1,400 euros. The payroll-tax rate is at its minimum (5.2\%) when the monthly wage equals $1,400 €$. When wages are between 1,400 and 1,600 euros, firms get the maximum subsidy of 220 euros. The subsidy is gradually reduced when wages increase above 1,600 euros so that the subsidy reaches zero when the monthly wage equals 2,000 euros. In this phase-out range the payroll taxes are strongly progressive with tax rates increasing from $7.2 \%$ at the wage level of $1,600 € /$ month to roughly $21 \%$ at the wage level of 2,000 €/month. Figure 1 illustrates the effects of the low-wage subsidy by plotting the reduction in the payroll tax due to the system and the corresponding average payroll tax rate.

\section{(Figure 1)}

Finland has no minimum wage laws. However, union contracts also cover non-union workers so that in practice the lowest legal wages are set in the union contracts for about 95 per cent of the workers. In the union contracts, the lowest wages vary across sectors, regions and tasks. In typical low-wage sector contracts, the lowest full-time wages were around 1,300 in 2006. In comparison one could note that according to Statistics Finland the average wage for full-time workers was around 2,500 euros in 2006. The subsidy is therefore targeted at workers that are well below the average wage, with the maximum subsidy paid to those whose wage is close to the minimum wage.

Since most full-time workers earn more than 1,400€/month, the subsidy both lowered the average payroll tax rate of target group workers, and made the payroll tax more progressive. The effects of progressivity on wages and employment crucially depend on whether the labour market is competitive or not. In competitive labour markets, an increase in progressivity typically reduces labour supply, whereas in an imperfect labour market, the opposite may hold. For example, in union models, a revenue-neutral increase in tax 
progressivity can increase employment, since it renders nominal wage increases less profitable for the unions, tilting the balance between employment and high wages in favour of increased employment (see e.g. Lockwood and Manning 1993, Holmlund and Kolm 1995 and Koskela and Vilmunen 1996). This is a relatively robust result that has garnered some empirical support, and it also holds under different labour-market imperfections (see e.g. the discussion in Sørensen 1997).

However, the mirror image of this result is that gross wages for low-paid workers may rise less than they would have risen in the absence of the progressive payroll tax system. ${ }^{11}$ Second, even if a rise in tax progressivity may increase employment at the extensive margin (i.e. the number of employees), it can still reduce the hours of work or, more generally, effort by individual workers at the intensive margin. ${ }^{12}$ Therefore, it is also important to account for how the hours that are worked change because of the reform.

\section{Employment rates by age}

As a first attempt to assess the employment effects of the wage subsidies we use data from the Finnish Labour Force Survey. We do not have micro-data at our disposal but we used employment rates and average hours per employed worker both calculated for one-year age groups. These data are unpublished tables produced for internal use at Statistics Finland. Statistical publications report similar numbers aggregated to five-year age groups.

We use data on employment rates and hours per employee for one-year age-groups between ages 46 and 60 from the period 2001 - 2007 and specify a simple difference-in-differences model that captures differences in employment rates across age groups and general trends in the labour markets. The effect of the subsidy scheme is captured by an interaction term, SUBSIDY $_{\mathrm{it}}$, indicating that the subsidy system has been implemented (year $\geq 2006$ ) and that the age-group is eligible for the subsidy (age $\geq 54$ ). The equation to be estimated is therefore

$$
y_{i t}=\alpha+\beta \text { SUBSIDY }_{i t}+\Omega_{i} D\left(\text { age }_{i}\right)+\Phi_{t} D\left(\text { year }_{t}\right)+\varepsilon_{i t},
$$

\footnotetext{
${ }^{11}$ This is, in fact, what some unions, where a large proportion of members are in the low-wage area, feared and therefore they opposed the introduction of the low-wage subsidy system.

12 This point had already been examined by Jackman and Layard (1990). In the long term, tax progressivity can also reduce the incentives to acquire education.
} 
where $y_{i t}$ is the variable of interest i.e. the employment rate or average hours of age group $i$ in year $t$. The coefficient $\beta$ is an unbiased estimate of eligibility for the subsidy if there are no other age-specific trends that are correlated with the subsidy scheme. As can be seen from Figure 2 this assumption is likely to be violated. Employment rates for the older age groups had been increasing for several years before the introduction of wage subsidies for reasons clearly unrelated to the subsidy scheme. To avoid interpreting these changes as an effect of wage subsidies for workers over 54 , we add age-specific linear trends to the equations that we estimate.

(Figure 2)

The results are displayed in Table 1 . We first report the effect of the subsidy on employment rates and then hours and per employee. The first two columns include both men and women. The next columns report the results for men and women separately. All equations include a full set of age and year dummies; coefficients of these dummy-variables are not reported in the table.

The estimates are reported in Columns 1, 3, and 5 indicate that the difference in the employment rates before and after the introduction of the subsidy system is on average 2.8 percentage points higher in the age groups eligible for the subsidy than in the younger age groups. Also, hours per employed worker seem to have increased by 21.9 hours per year or by about 1.4 percent. However, both these changes seem to be due to a general increase in employment in the older age groups. After adding cohort-specific trends to the equations the estimated effects decrease close to zero and are not significant in any specification.

(Table 1)

If the employment rates of the older age groups had increased after the reform we should have been able to detect them by using data from the Labour Force Survey. Focusing on the employment rates instead of the number of employed workers also captures the changes in the cohort size effectively controlling for the changes in the labour supply. The drawback to the Labour Force Survey is that information on wages or education is not available. Hence, we could not capture differential changes in low-wage and high-wage employment. This is why we now proceed to triple differences (DDD) analysis, first in Section 5, on exit from unemployment using register-data of the unemployed and, second in Section 6, on job leaving rates, hours of work and wage rates using data from the employers’ organisation. 


\section{Entry of the unemployed to the workforce}

We analyse the effect of the subsidy on re-employment rates using individual-level data from Finnish Longitudinal Census files. The data contains a 33\% random sample of population that resided in Finland at some point between 1990 and 2006 and hence also a random sample of the unemployed at any given point in time. We take three separate cross-sections of data containing those who were unemployed in the last week of the years 2003, 2004 and 2005 and examine their employment status in the end of the following year. To focus on the elderly unemployed we limit the data to those between the ages of 45 and 59 at the time when we draw the samples i.e between 46 and 60 when we measure their labor market outcomes. The unemployed in the first two cross-sections are not eligible for the subsidy but those who were unemployed in the end of 2005 become eligible from the beginning of 2006 if they are over 54 years old in 2006.

We define the treatment group as those who are eligible for the subsidy, i.e. those whose monthly wages are less than 2,000 EUR and who are over 54 years old. Since wages for the unemployed are not available, we cannot create treatment and control groups based on the current wage level. As a partial solution we split the data by education into those with no more than basic education and those with at least a secondary education; and by previous wage into those whose pre-unemployment monthly wage was below 2,000 EUR and those whose pre-unemployment wage was higher than that. Pre-unemployment wages are based on months worked and annual income received during the previous year. To avoid excessive measurement errors we only included data on those who had worked at least six months during the calendar year. Since many unemployed workers have incomplete earnings histories we could calculate reliable pre-unemployment wages for only about half of the sample. We have thus two alternative treatment groups in this section: The 54-60 -year-old workers whose pre-employment monthly wages were below 2,000 EUR or the 54-60 -year-old workers who have no more than basic education. Workers who are younger than 54 or whose preemployment monthly wages were above 2,000 EUR (or who have more than basic education) are used as control group.

We begin by estimating the effect of low wage subsidy on re-employment rates of unemployed workers. The estimated equation has the following form: 


$$
\begin{aligned}
& P\left(E_{i t}=1 \mid E_{i t-1}=0\right)=\alpha+\beta_{1} X_{i t}+\beta_{2} Y E A R+\beta_{3} A G E G+\beta_{4} W A G E G_{, t-1}+\beta_{5}\left(A G E G * W A G E G_{, t-1}\right) \\
& +\beta_{6}\left(Y E A R_{\imath} * A G E G\right)+\beta_{7}\left(Y E A R_{\imath} * W A G E G_{, t-1}\right)+\beta_{8}\left(Y E A R * A G E G * W A G E G_{, t-1}\right)
\end{aligned}
$$

In this equation $\mathrm{i}$ indexes individuals, $\mathrm{t}$ indexes years and $P\left(E_{i t}=1 \mid E_{i t-1}=0\right)$ is the probability that an unemployed worker finds employment between t-1 and t. $X_{i t}$ is a vector of individual characteristics, YEAR controls for common time shocks, AGEG is an age group dummy, which controls for permanent differences between older and younger workers, WAGEG is a wage group dummy (based on previous earnings or education level), which controls for permanent differences between low-wage (low-skill) and high-wage (high-skill) workers, AGEG*WAGEG controls for time-invariant characteristics of the treatment group, YEAR*AGEG controls for the time-specific shocks that affect the outcome of older workers, and YEAR*WAGEG captures the time-specific shocks common to low-wage (or low-skill) workers. The third level interaction term $\left(\beta_{8}\right)$ captures all variations in the outcome specific to older low-wage (or low-skilled) workers after the introduction of the low-wage subsidy scheme. This is the "difference-in-difference-in-differences” (DDD) estimator. Its identifying assumption is that there is no contemporaneous shock that affects the relative outcomes of the treatment group differently than other older workers or other low-wage (low-skill) workers.

Table 2 presents the main results of the exercise. First, in Column 1 we presents difference-indifference-in-differences estimates i.e. the coefficient of a triple interaction between the postreform period, age over 54 and only compulsory education while controlling for the pair-wise interactions between these variables. The coefficient is positive, indicating that the reemployment rates of the unemployed that are more likely to be eligible for the subsidy increase by one per cent due to the reform. However, this estimate is not statistically significant. In the second column we use an indicator of previous wages that are below 2,000 euro instead of an indicator of low education. Since data on previous wages is missing for many observations the sample size is dramatically reduced. The estimate is larger than in the previous column but still insignificantly different from zero. In Column 3 we limit the comparison group to those whose previous monthly wage is below 3,000 euro and in Column 4 exclude the unemployed who are 55 because their early retirement benefits changed in 2005 in a way that is likely to increase re-employment incentives. Neither has much effect on the estimates. $^{13}$

\footnotetext{
${ }^{13}$ An earlier decided pension reform came into force during the same time, affecting the early retirement incentives of all 55 year olds (not only low-income older workers).
} 
(Table 2)

\section{The impact of the low-wage subsidy on job exit rates, wages and working hours}

In this section we examine the impact of the low-wage subsidy scheme on the probability of exiting from current employment. As entry into new jobs is relatively rare at old ages, reducing exits could be a key channel to how the subsidy could affect employment. In addition we examine the effect of low-wage subsidy on wages and working hours.

The data for this section come from the payroll records of the Finnish employers' association. The data cover all private sector workers except the firm's top management in firms that are members of the association and provide information about monthly wages, working time, and some information about workers' individual characteristics such as age, gender and education. The data contains pseudo ID codes identifying each person and each firm that allow the same person to be followed over time as long as the person remains employed by a firm that is included in the data. In addition, we have access to register data from the tax authorities that includes the actual subsidies paid to all individuals in Finland.

The main benefit of the data is that wages are accurately reported. In most firms the wage data comes directly from the firm's pay system. Hours are also reported accurately in the firms that pay hourly wages. The firms that pay monthly salaries typically only report normal weekly hours. Even this information is likely to be more reliable than self-reported hours in household surveys.

The sample that we use in the empirical analysis is constructed as follows. We have two years of data before the reform (2004 and 2005) and two years after the reform (2006 and 2007). We drew four separate samples: for each year; we take those employed at the end of the previous year (t-1) and follow them until the end of year t. To limit the comparison group to reasonably similar workers we restricted both samples to those over 45 and below 59 years at the time when the wage information was collected (time t-1). In addition, we only consider employees whose wage is less than $3,000 €$ per month. 
We determine eligibility for the subsidy based on age and monthly wage in year t-1, and calculate the subsidy based on monthly wage in that year. We begin by dividing the data into two age groups (below 54/above 54) and two wage groups (below 2,000/above 2,000). We thus have four different age-wage categories. Our treatment group is the workers who are eligible for the subsidy, i.e. older low-wage workers. Notice that we do not restrict the treatment group to full-time workers. If we did this, we would not capture the possibility that a part-time worker could become a full-time worker because of the introduction of the subsidy. ${ }^{14}$

Table 3 collects some descriptive analysis of the target and the control group in the postreform years, 2006 and 2007. Most eligible workers work in the service sector. The share of female workers in the treatment group is higher than their average share in both sectors. Not surprisingly, workers in the treatment group are also less educated than other workers. The mean wage in the eligible group is at the phase-out range of the subsidy, suggesting that most of the employers of the target group workers face a progressive payroll tax system.

The table also reports the share of those who actually received the subsidy among the eligible. The take-up rate is calculated as the share of those who actually received the benefit in year $\mathrm{t}$ according to data from the Tax Register to those who would eligible for the benefit according to the wage and the working hours reported in the employers' association data. Not all employers of the eligible used the subsidy. The take-up rate is $64 \%$ in the service sector and $56 \%$ in the industrial sector. ${ }^{15} 16$

(Table 3)

We begin by estimating the effect of the low-wage subsidy on the job exit rate. We defined those who were not found in the same firm the next year as leavers. As previously we use the

\footnotetext{
${ }^{14}$ On the other hand, the treatment group now includes part-time workers who are not eligible for the subsidy. We also analysed the case where the treatment group was restricted to full-time workers. See the discussion at the end of Section 6.

${ }^{15}$ Analysis of the take-up rate reveals that take-up is higher in bigger firms and in firms where the mean wage is smaller than the average. Representatives of the federations of industries and entrepreneurs have suggested that cumbersome administrative details related to the subsidy system may explain why some firms have not applied for the subsidies.

${ }^{16}$ In our analysis eligibility is defined using the previous year's earnings and age, and thus the share of workers who actually received the subsidy is even lower than when measured by current earnings and working hours in the year when subsidy scheme was at place. The take-up rate for the eligible in this set up is 0.42 in the industrial sector and 0.52 in the service sector. Some people in the non-eligible group also received the subsidy, the share is 0.02 for the service sector and 0.01 for the industrial sector.
} 
difference-in-difference-in-differences strategy. The regression equation has a form similar to Equation (2) in Section 5:

$$
\begin{aligned}
& P\left(E_{i t}=1 \mid E_{i t-1}=0\right)=\alpha+\beta_{1} X_{i t-1}+\beta_{2} Y E A R+\beta_{3} A G E G+\beta_{4} W A G E G_{t,-1}+\beta_{5}\left(A_{G E G} * W A G E G_{t,-1}\right) \\
& +\beta_{6}(Y E A R * A G E G)+\beta_{7}\left(Y E A R * W A G E G_{, t-1}\right)+\beta_{8}\left(Y E A R * A G E G * W A G E G_{, t-1}\right)
\end{aligned}
$$

In this equation $P\left(E_{i t}=0 \mid E_{i t-1}=1\right)$ is the probability that a worker leaves a firm between $t-1$ and $t$. The WAGEG variable is now an indicator variable that gets value one if the monthly wages in year $t$-1 were below 2,000 EUR. As explained in section 5, this specification controls for any permanent differences between treatment and control groups as well as any simultaneous changes affecting employment of all older workers or employment of all lowwage workers at the time when the low-wage subsidy was introduced. The third level interaction term $\left(\beta_{8}\right)$ captures all variations in outcome specific to older low-wage workers after the introduction of the low-wage subsidy scheme.

We also estimate a specification where we replaced the treatment-dummy variable $\left(Y E A R_{t} * A G E G * W A G E G\right)$ with the amount of the subsidy the employer would be eligible for. Now the effect of the subsidy is also identified from the differences in the size of the subsidy among the eligible group. Since the size of the subsidy depends on the wage level we replace the rough low-wage high-wage groups with finer 100 euro wage intervals. At the same time we fully control for age by including it as one-year age dummies.

We calculated the low-wage subsidy that the firm would get for each worker in year $t$ if his/her wage remained unchanged from year $\mathrm{t}-1$. Since the payroll tax subsidy was introduced only in 2006, this measure is zero for all workers in the 2003 and 2004 samples. For the 2005 sample the measure gets positive values if the 2005 wage is below 2,000 euros and if the worker is over 53 (i.e. over 54 and hence eligible in 2006), and likewise for the 2006 sample. Our model is therefore identified from the differences in the changes in job-leaving rates between the group that becomes eligible for the low-wage subsidies and groups that are either too young to be eligible or have a wage exceeding 2,000 euro. In both cases we estimate the impacts of the eligibility for the low-wage subsidy, not the effect of actually receiving the 
subsidy. As we report in the empirical section, the take-up rates were well below 100 per cent, indicating that not all firms that are eligible for the subsidy ever apply for $\mathrm{it}^{17}$.

We use a similar specification when we examine the effects on hours and wages conditional on employment. In this analysis of adjustment in the intensive margin we limit the data to those who are employed in the same firm in both years $t-1$ and t. The dependent variable is either log hourly wages or log weekly hours.

Table 4 illustrates a DDD estimation of the effect of low-wage subsidy on job-leaving rates for the industrial sector. The upper panel compares the change in job exit rates for older lowwage workers (treatment individuals) before and after the introduction of the low-wage subsidy scheme with the change in the job exit rates of younger low-wage workers. Each cell contains the mean job-leaving rate for the group labelled on the axes, along with standard errors and the number of observations. There is a clear fall in the job-leaving rates for both groups during this period. The difference-in-differences estimate, i.e. the difference in the changes of the job-leaving rate between older and younger low-wage workers is -2.5 per cent. If there was a distinct labour market shock that affected older workers over this period, this estimate would not correctly identify the impact of the low-wage subsidy scheme. In the bottom panel we perform the same exercise for high-wage workers. The difference between the change in the job-leaving rate for older and younger high-wage workers is also negative, 2.1 per cent. Taking the difference between these two panels, we get the DDD estimate, which is negative but not statistically significant.

In the lower panel we perform the same exercise for service sector workers. The DD between older and younger low-wage workers indicates a 2.2 per cent fall in the job-leaving rate. This difference is similar for high-wage workers (2.5 per cent). According to the lower panel, the DDD estimate indicates that there was no change in the job-leaving rate of the target group. The results in this table demonstrate the power and importance of the DDD estimation. Without the other control group, one would mistakenly conclude that the subsidy system was effective in reducing exit rates.

The first row of Table 5 presents the results of the same analysis in a regression framework. We first re-report the coefficient of the treatment variable (older*low-wage*after) in our DDD specification for industrial sector workers. We estimate this linear probability model by

\footnotetext{
${ }^{17}$ Our results should therefore be interpreted as effects of eligibility, or intention to treat effect.
} 
OLS. In Column 2 we control for other observables, such as educational category (4), gender, union contract, and two-digit industry. Adding these control variables does not render the coefficient significant.

The lower panel reports the results of a specification where we explain the job-leaving rate by the amount of the subsidy the worker's employer is eligible for (in 100 euro). The specification in the first column includes controls for age-group, wage-group and time period. In the next column we report the results for a specification which controls for time-specific shocks to age- and wage-groups, as well as age-group wage-group interaction. Now we find that even if we take into account the actual amount of the subsidy the employers could be eligible for, the system is still not effective in reducing exit rates. The result remains when controls for gender, education and industry are included.

Columns 3 and 4 report the same estimations for service-sector workers. The additional control variables include dummies for gender, educational category and educational field. The results indicate that subsidy scheme had not impact on job leaving rate.

Since a simultaneous pension reform made it easier for 55-year-old workers to leave to earlyretirement, we have checked the robustness of the results when this age group is dropped from the sample. The qualitative results remain the same: the exit rates did not decline in a statistically significant way in either sector. ${ }^{18}$

Next, we analyse how low-wage subsidies affected working hours and earnings for those who remained with their employer. Table 6 reports the OLS estimates of the third-level interaction from equation (1), where the dependent variable is now the log weekly working hours. From the upper panel, we find that the introduction of the wage subsidy increased the working hours for older workers in the industrial sector by almost 4.5 per cent. The lower panel suggests, however, that when measured by the actual amount of the subsidy the employers are eligible for, the impact on working hours decreases to 1.8 per cent. There are probably some non-linear effects on working hours, depending on the workers' wage level. There seems to be no effect of the low-wage subsidy for service-sector workers. We also investigated whether this increase in working hours was due to a possible increase in the share of full-time workers within the group of older low-wage workers. Our results (not reported) indicated that the low-

\footnotetext{
${ }^{18}$ These results are available from the authors upon request.
} 
wage subsidy did, in fact, significantly increase the likelihood of becoming a full-time worker for part-time workers in the industrial sector ${ }^{19}$.

Table 7 reports the results of regression where the dependent variable is log real hourly wages. The sample consists of stayers, i.e. workers who have remained with the same employer for at least two periods. For the industrial sector there seems to be an almost 2 per cent decrease in hourly wages. For the service sector the results are less clear. The low wage subsidy had no or very little effect on hourly wages ${ }^{20}$.

All these estimations were carried out using the subsidy eligibility definition, which is based on age and earnings in year $t$ - 1 . This includes both part-time and full-time workers. As a robustness check we examined how results change if eligibility for the subsidy is restricted only to full-time workers in year $t-1$. We included controls for full-time work in time $t-1$ in these regressions. This did not have an effect on our results.

\section{Some Extensions}

As noted above, the comparison of changes in the exit rates, hours worked and wages between those who are eligible for the low-wage subsidy and those who are not reveals the impact of the reform, not the impact of actually receiving wage subsidies. As long as we are primarily concerned about the effects of introducing a low-wage subsidy policy, this is probably the main parameter of interest. However, incomplete take-up is likely to lead to smaller employment effects than a policy that would automatically reduce payroll taxes for the eligible workers. If we are interested in evaluating the effects of actually receiving low-wage subsidies or in identifying labour demand elasticities due to a reduction in the labour costs, we need to account for the incomplete take-up rates.

Moving away from analysing the effects of the policy change to the effects of a reduction in payroll taxes immediately introduces serious selectivity problems. Thus, in order to calculate the effects of actually receiving the subsidy we use eligibility for subsidy as an instrument for receiving subsidy. In the simplest case, where both the eligibility for the subsidy and

\footnotetext{
${ }^{19}$ The subsidy increased the likelihood of becoming a full-time worker by 7 per cent. Subsidies had no impact on the working hours of workers who were already full-time workers in year $t$.

${ }^{20}$ Even though the hourly wages decreased in the industrial sector, the monthly wages increased, since there was an overall increase in working hours.
} 
recipiency of the subsidy are dummy variables, the IV estimate for the effect of the subsidy is the Wald estimate

$$
\beta_{W A L D}=\frac{E\left[Y_{i} \mid R_{i}=1\right]-E\left[Y_{i} \mid R_{i}=0\right]}{E\left[S_{i} \mid R_{i}=1\right]-E\left[S_{i} \mid R_{i}=0\right]}
$$

where $Y$ is the outcome of interest, $S$ indicates that the firm receives subsidies for worker $\mathrm{i}$. The numerator in this expression is the difference in the outcome variable between the persons that are eligible for the subsidy, and the denominator is the difference in the fraction actually receiving the subsidy. If receiving the subsidy is impossible for those who are not eligible for the subsidy $E\left[S_{i} \mid R_{i}=0\right]=0$, the Wald estimate simply scales up the effects by multiplying the difference between eligible and ineligible persons by the inverse of the takeup rate.

One should also note that as long as eligibility for the subsidy has some effect on the fraction receiving subsidies the denominator of the equation is strictly positive, and inferences on whether the effect is significantly different from zero can be based directly on the numerator. Hence, if eligibility for the subsidy has no significant effect on the outcome of interest, neither has actually receiving the subsidy had any effect.

To illustrate the role of the take-up rate, we show the impact of actually receiving the subsidy on working hours when eligibility for the subsidy is used as an instrument for received subsidies (Table 8). As expected, the point estimate of the subsidy has increased in the industrial sector: since the take-up rate is close to $50 \%$, the coefficient of the actual subsidy is roughly two times larger than the coefficient of eligibility alone. In the service sector, since the effects of eligibility are not significant, neither are the impacts of actually receiving the subsidy. The results regarding earnings (not shown) follow the same pattern.

The usual worry with the targeted subsidy systems is whether they lead to substitution or replacement effects. This 'revolving door' issue may arise if employers simply shed ineligible workers to be able to benefit more from the subsidies for eligible workers. Then even if the share of the targeted workers rises, overall employment may not necessarily increase. Given that we did not find statistically significant employment effects for the target group, there is little need to examine the substitution effects in our case. 
Finally, if the goods market is non-competitive, the tax cut may also lead to increased profits because the market prices of the final goods do not necessarily move in a one-to-one relation with marginal costs. (See the analysis in e.g. Myles, Ch. 11, (1995) for commodity taxes; the analytics are similar with respect to the taxation on labour.) Our analysis using data on financial statements of Finnish corporations, combined with information about firm-specific low-wage subsidies, does not seem to reveal robust linkages between the amount of subsidies received and the profit rates. ${ }^{21}$

\section{Conclusions}

While low-wage subsidies are often regarded as a promising way to improve the labourmarket prospects of low-skilled workers, the current evidence on their effectiveness is scarce. The evidence is mainly based on universal subsidy schemes that are difficult to evaluate because of the lack of a natural comparison group. Using detailed, individual-level, panel data, this paper estimated the employment effects of a Finnish low-wage subsidy scheme that was targeted to low-wage older workers. The clear eligibility criteria opened up a way to use the DDD estimation strategy that allows for controlling for, for example, time-varying differences for labour demand of a given skill category. In fact, we find that leaving out the other control group, essentially returning to the standard DiD analysis similar to earlier papers in the field, would produce upwards-biased estimates of the impacts of the subsidy system.

The results indicate that the subsidy scheme was not effective in increasing the employment of eligible workers. However, it might have led to increased working hours in the industrial sector by making some former part-time workers work full-time. The results regarding the impacts on wages are somewhat ambiguous: monthly wages rise, but hourly wages (in comparison to wages in the control groups) seem to have dropped in some cases. This is interesting because it is, in fact, one of the theoretical predictions of the impacts of progressive taxes under imperfectly competitive labour markets.

Quite why the results are so disappointing remains unclear. Perhaps the subsidy has not been sufficiently large, given that the treatment group (elderly workers) can consist of workers for

\footnotetext{
21 This issue was analysed using register-data of all Finnish corporations, available from the tax authorities, from 2004-2007. The profit rate (profit/turnover) was explained in a fixed-effects framework by the subsidy (divided by turnover) the firm received and firm and year dummies. This analysis did not provide evidence that subsidies had increased the profitability of the subset of firms that received them.
} 
whom it is particularly difficult to remain employed or to be hired. Or perhaps the wage demand for these workers is simply inelastic. Needless to say, these results cannot be regarded as a universal case against low-wage subsidies. What they demonstrate is the need for careful evaluation of these schemes that can, one hopes, in the end, help design the schemes in the best possible way.

\section{References:}

Bell, B., R. Blundell and J. Van Reenen (1999) 'Getting the Unemployed Back to Work: The Role of Targeted Wage Subsidies’, International Tax and Public Finance, 6, 339-360

Blundell, R., M. Costa Dias, C. Meghir and J.Van Reenen, 2004. "Evaluating the Employment Impact of a Mandatory Job Search Program," Journal of the European Economic Association, MIT Press, vol. 2(4), pages 569-606, 06.

Blundell, R. (2006) 'Earned Income Tax Credit Policies: Impact and Optimality, The Adam Smith Lecture 2005’, Labour Economics 13, 423-443.

Bovenberg, L., J. Graafland and R.A. de Mooij (2000) 'Tax reform and the Dutch labor market: an applied general equilibrium approach', Journal of Public Economics 78, 193-214.

Brown, A., C. Merkl and D. Snower (2007) 'Comparing the effectiveness of low-wage subsidies’, CEPR Discussion Paper No. 6334.

Card, D. and D. Hyslop (2005) 'Estimating the Effects of a Time-Limited Earnings Subsidy for Welfare Leavers’ Econometrica, 73 (6), 1723-1770

Chéron, A., J.-O. Hairault and F. Langot, (2008) 'A quantitative evaluation of payroll tax subsidies for low-wage workers: An equilibrium search framework', Journal of Public Economics 92, 817-843.

Crépon B. and R. Desplatz (2003) 'Evaluating the effects of payroll tax subsidies for low wage workers on Firm Level Decisions’, INSEE, Document du travail du CREST 200306 
Drèze, J.H. and E. Malinvaud (1994) 'Growth and Employment: The Scope for a European Initiative', European Economy, No. 1. 77-106.

Edlin, A. and E. Phelps (2009) 'Getting serious about job creation: Part I', The Economists' Voice 6, Issue 5, Article 3.

Eissa, N. and H. Hoynes (2004) 'Taxes and the labor market participation of married couples: the earned income tax credit', Journal of Public Economics 88, 1931-1958.

Eissa, N. and J. Liebman (1996) 'Labor supply response to the earned income tax credit' Quarterly Journal of Economics CXI, 605-637.

Gesine, S. (2009) Employer wage subsidies and wages in Germany. IAB Discussion Paper 9/2009.

Goos, M. and J. Konings (2007), 'The Impact of Payroll Tax Reductions on Employment and Wages: A Natural Experiment Using Firm Level Data,' LICOS Discussion Papers 17807.

Gruber J (1994) “The Incidence of Mandated Maternity Benefits” American Economic Review 84(3), 622-641.

Gruber J (1997) The Incidence of Payroll Taxation: Evidence from Chile, Journal of Labor Economics, 15 (3, Part 2), S72-S101

Holmlund, B. and A.-S. Kolm (1995) 'Progressive Taxation, Wage Setting, and Unemployment: Theory and Swedish Evidence. Swedish Economic Policy Review 2, 423-460.

Jackman, R. and R. Layard (1990) 'The Real Effects of Tax-based Incomes Policies', Scandinavian Journal of Economics 92, 309-324.

Katz, L. (1996) ‘Wage subsidies for the disadvantaged’ NBER Working Paper 5679.

Knabe, A. and R. Schöb (2008) 'Minimum wages and their alternatives: A critical assessment', CESifo Working Paper No. 2494.

Knabe, A., R. Schöb and J. Weimann (2006) 'Marginal employment subsidization: A new concept and a reappraisal', Kyklos 59, 557-577. 
Korkeamäki, O. and R. Uusitalo (2009) 'Employment and wage effects of a payroll-tax cut: Evidence from a regional experiment', International Tax and Public Finance, forthcoming.

Koskela, E. and J. Vilmunen (1996) 'Tax Progression is Good for Employment in Popular Models of Trade Union Behaviour', Labour Economics 3, 65-80.

Kramarz, F. and T. Philippon (2001) 'The impact of differential payroll tax subsidies on minimum wage employment', Journal of Public Economics 82, 115-146.

Lockwood B and Manning A. (1993) Wage setting and the tax system. Theory and evidence for the United Kingdom. Journal of Public Economics 52:1-29

Myles, G. (1995) Public Economics. Cambridge University Press.

Phelps, E. (1994) “Low-Wage Employment Subsidies versus the Welfare State”, American Economic Review, Papers and Proceedings ,84, 54-58.

Phelps, E. (1997) Rewarding Work: How to Restore Participation and Self-Support to Free Enterprise, Cambridge, MA: Harvard University Press.

Sørensen, P.B. (1997) 'Public Finance Solutions to the European Unemployment Problem?' Economic Policy October 1997, 223-264. 


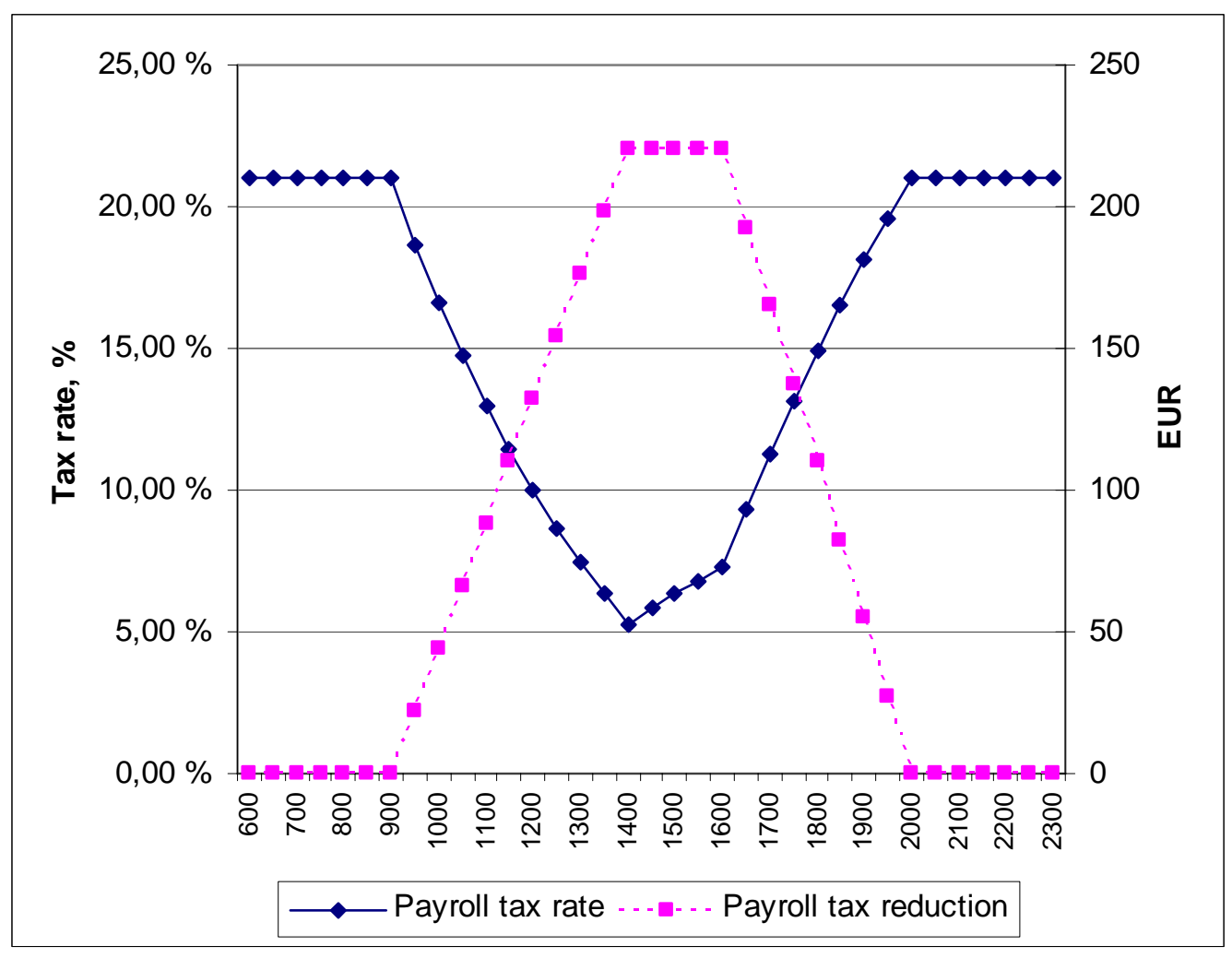

Figure 1: The payroll tax reduction due to the Finnish low-wage subsidy system (right axis) and the corresponding average payroll tax rate (left axis), when the payroll tax without a subsidy is a proportional $21 \%$ tax. 


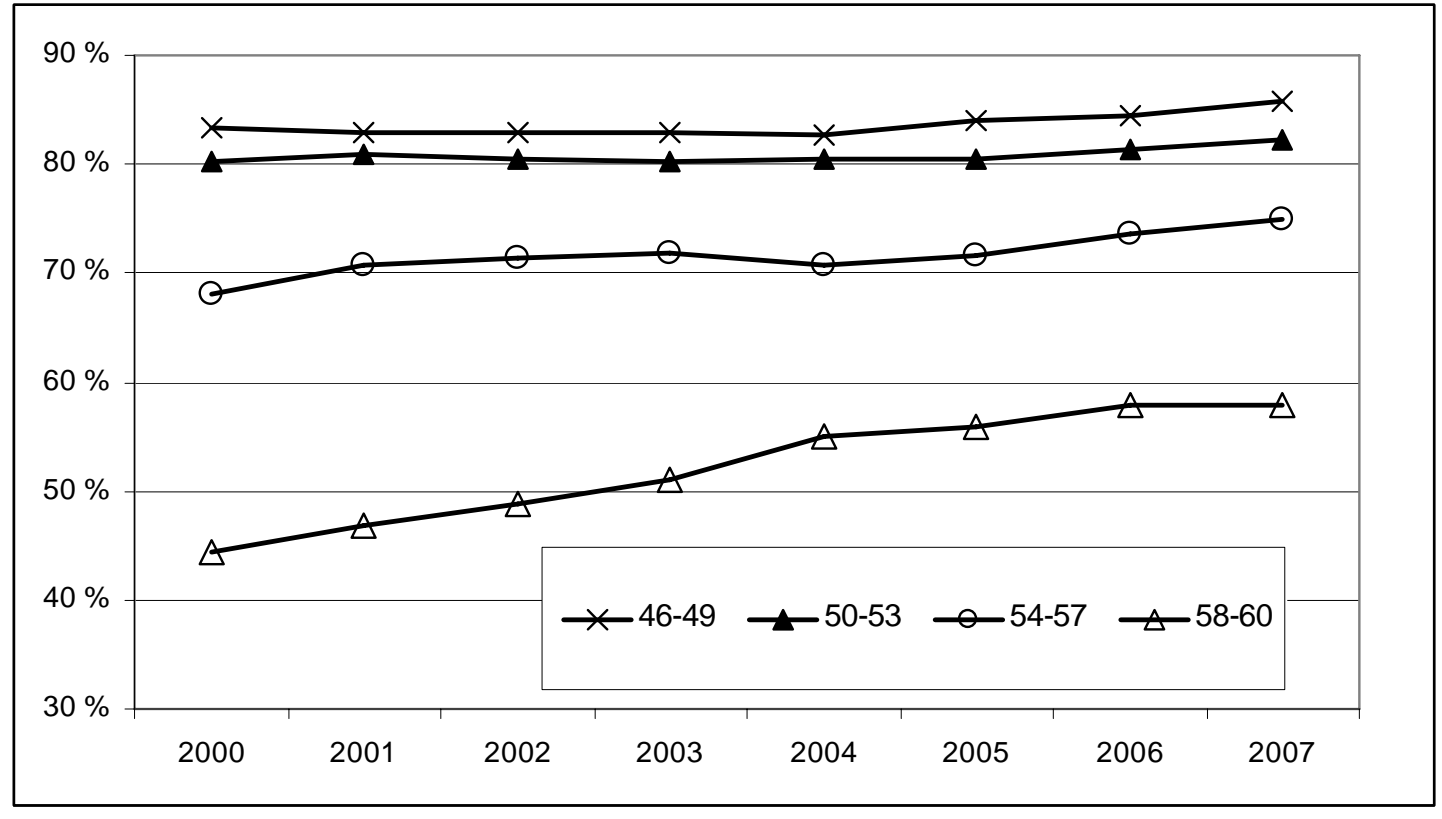

Figure 2. Employment rates of selected age-groups in $2000-2007$ 
Table 1. Difference-in-differences estimates on employment rates.

\begin{tabular}{|c|c|c|c|c|c|c|}
\hline \multirow[t]{2}{*}{ Employment rate } & \multicolumn{2}{|c|}{ All } & \multicolumn{2}{|c|}{ Men } & \multicolumn{2}{|c|}{ Women } \\
\hline & 1 & 2 & 3 & 4 & 5 & 6 \\
\hline Subsidy & $\begin{array}{c}0.028 * * * \\
(0.008)\end{array}$ & $\begin{array}{l}-0.006 \\
(0.010)\end{array}$ & $\begin{array}{c}0.021 * * \\
(0.010)\end{array}$ & $\begin{array}{c}-0.006 \\
(0.014)\end{array}$ & $\begin{array}{c}0.035^{* * *} \\
(0.009)\end{array}$ & $\begin{array}{l}-0.008 \\
(0.011)\end{array}$ \\
\hline Year effects & yes & yes & yes & yes & yes & yes \\
\hline Age effects & yes & yes & yes & yes & yes & yes \\
\hline Age-specific trends & & yes & & yes & & yes \\
\hline $\mathrm{N}$ & 105 & 105 & 105 & 105 & 105 & 105 \\
\hline Adj $R^{2}$ & 0.98 & 0.99 & 0.96 & 0.97 & 0.97 & 0.99 \\
\hline
\end{tabular}

\begin{tabular}{lcccccc}
\hline Hours & \multicolumn{2}{c}{ All } & \multicolumn{2}{c}{ Men } & \multicolumn{2}{c}{ Women } \\
& 1 & 2 & 3 & 4 & 5 & 6 \\
\hline \multirow{2}{*}{ Subsidy } & & & & & & \\
& $21.9 * *$ & -7.8 & 26.4 & -11.2 & 20.9 & 0.2 \\
Year effects & $(14.1)$ & $(21.7)$ & $(22.1)$ & $(35.6)$ & $(15.1)$ & $(24.4)$ \\
Age effects & yes & yes & Yes & yes & yes & yes \\
Age-specific trends & yes & yes & Yes & yes & yes & yes \\
\hline $\mathrm{N}$ & 105 & yes & & yes & & yes \\
Adj $\mathrm{R}^{2}$ & 0.87 & 0.88 & 0.71 & 105 & 105 & 105 \\
\hline \multicolumn{2}{l}{ Standard errors in parentheses, $* \mathrm{p}<.1 ; * * \mathrm{p}<.05 ; * * *$} & 0.72 & 0.86 & 0.86 \\
\hline
\end{tabular}

Standard errors in parentheses, ${ }^{*} \mathrm{p}<.1{ }^{* *} \mathrm{p}<.05$; ${ }^{* * *} \mathrm{p}<.01$

\begin{tabular}{lcccccc}
\hline Log hours & \multicolumn{2}{c}{ All } & \multicolumn{2}{c}{ Men } & \multicolumn{2}{c}{ Women } \\
& 1 & 2 & 3 & 4 & 5 & 6 \\
\hline \multirow{2}{*}{ Subsidy } & & & & & & \\
& 0.014 & -0.004 & 0.015 & -0.006 & 0.014 & 0.001 \\
Year effects & $(0.009)$ & $(0.013)$ & $(0.013)$ & $(0.020)$ & $(0.010)$ & $(0.016)$ \\
Age effects & yes & yes & yes & yes & yes & yes \\
Age-specific trends & yes & yes & yes & yes & yes & yes \\
\hline $\mathrm{N}$ & & yes & & yes & & yes \\
Adj R & 105 & 105 & 105 & 105 & 105 & 105 \\
\hline Stances & 0.87 & 0.88 & 0.71 & 0.72 & 0.86 & 0.86 \\
\hline
\end{tabular}

Standard errors in parentheses, ${ }^{*} \mathrm{p}<.1 ;{ }^{* *} \mathrm{p}<.05 ;{ }^{* * *} \mathrm{p}<.01$ 
Table 2. The effect of the subsidy on re-employment rates

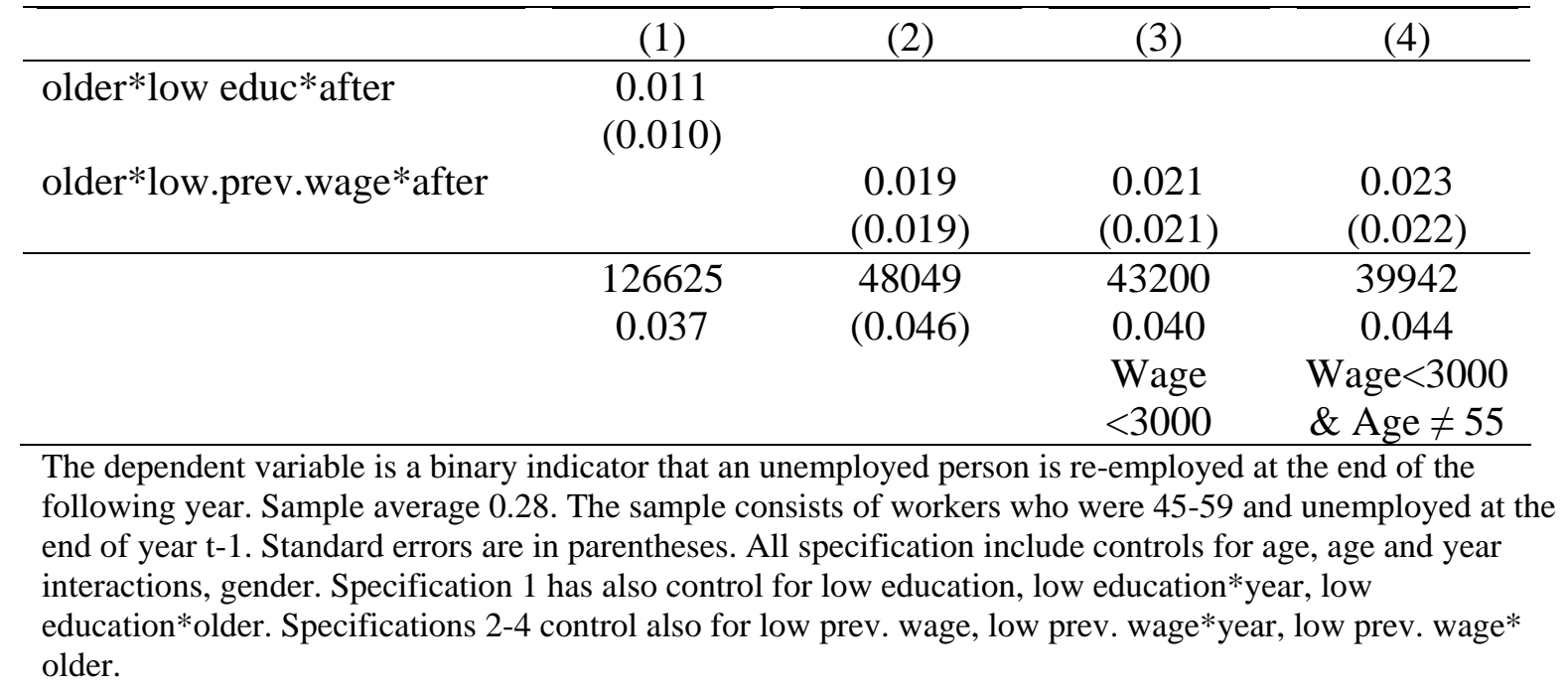


Table 3. Descriptive statistics from payroll data

\begin{tabular}{lcccc}
\hline & \multicolumn{2}{c}{ Service sector } & \multicolumn{2}{c}{ Industrial sector } \\
& Eligible* & Others & Eligible* & Others \\
\hline Obs & 17159 & 87146 & 13332 & 105573 \\
Female & 0.87 & 0.81 & 0.55 & 0.25 \\
Basic edu & 0.45 & 0.23 & 0.55 & 0.37 \\
Secondary edu & 0.46 & 0.42 & 0.40 & 0.59 \\
Academic edu & 0.10 & 0.36 & 0.04 & 0.04 \\
Age at t-1 & 55.81 & 50.79 & 55.81 & 51.29 \\
Wage at t-1 & 1724 & 2221 & 1702 & 2359 \\
Fulltime at t-1 & 0.90 & 0.96 & 0.82 & 0.99 \\
\hline Take-up rate $* *$ & 0.64 & & 0.56 & \\
Subsidy ** & 66.71 & & 142.11 & \\
\hline
\end{tabular}

*Eligibility is defined as having a wage between 900-2000 euros a month in year t-1 and being over 53 years old in year $\mathrm{t}-1$. **Mean monthly value of the subsidy in year $\mathrm{t}$ for those who received any subsidy. This table was prepared using only (post reform) years 2006 and 2007. The take-up rates are calculated using actual realised wages and working hours (unlike in regressions where eligibility is determined on the basis of wages at the previous period, without working hours restrictions). 
Table 4. DDD Estimates of the impact of low-wage subsidy on exit rate

\begin{tabular}{lcccc}
\hline Wage $<2000$ & \multicolumn{3}{c}{ Industrial sector } \\
& before & after & difference & diff-in-diff \\
\hline age $>54$ & .248 & .191 & -.056 & \\
& $(.431)$ & $(.393)$ & $(.005)$ & \\
age $<54$ & {$[13158]$} & {$[13332]$} & & \\
& .207 & .176 & -.031 & -.025 \\
& $(.405)$ & $(.381)$ & $(.004)$ & $(.008)$ \\
\hline Wage $>$ & {$[15606]$} & {$[15596]$} & & \\
\hline
\end{tabular}

\begin{tabular}{|c|c|c|c|c|}
\hline $\begin{array}{l}\text { Wage }> \\
2000-3000\end{array}$ & Before & After & difference & diff-in-diff \\
\hline \multirow[t]{3}{*}{ age $>54$} & .219 & .199 & -.020 & \\
\hline & $(.414)$ & (.399) & $(.003)$ & \\
\hline & [40251] & [40349] & & \\
\hline \multirow[t]{4}{*}{ age $<54$} & .178 & .177 & .001 & -.021 \\
\hline & $(.381)$ & $(.382)$ & $(.002)$ & $(.004)$ \\
\hline & [55444] & [49628] & & \\
\hline & & & DDD: & $\begin{array}{l}-.004 \\
(.008)\end{array}$ \\
\hline \multicolumn{5}{|c|}{ Service sector } \\
\hline \multicolumn{5}{|l|}{ Wage $<2000$} \\
\hline & Before & after & difference & diff-in-diff \\
\hline \multirow[t]{3}{*}{ age $>54$} & .266 & .269 & .003 & \\
\hline & $(.441)$ & $(.443)$ & $(.005)$ & \\
\hline & [13458] & [17159] & & \\
\hline \multirow[t]{3}{*}{ age $<54$} & .233 & .259 & .025 & -.022 \\
\hline & $(.423)$ & $(.438)$ & $(.004)$ & $(.007)$ \\
\hline & [19588] & [23434] & & \\
\hline \multicolumn{5}{|l|}{$\begin{array}{l}\text { Wage 2000- } \\
3000\end{array}$} \\
\hline & Before & after & difference & diff-in-diff \\
\hline \multirow[t]{3}{*}{ age $>54$} & .157 & .163 & .006 & \\
\hline & $(.364)$ & $(.369)$ & $(.003)$ & \\
\hline & [19939] & [26878] & & \\
\hline \multirow[t]{4}{*}{ age $<54$} & .134 & .165 & .031 & -.025 \\
\hline & $(.340)$ & $(.371)$ & $(.003)$ & $(.004)$ \\
\hline & [30203] & [36834] & & \\
\hline & & & DDD: & $\begin{array}{l}.003 \\
(.008)\end{array}$ \\
\hline
\end{tabular}

Each cell contains mean exit rate (job leaving rate between t-1 and t) for the group identified. Standard errors are given in parentheses; sample sizes are given in square brackets. Sample consist of 45-59 years old workers in year $\mathrm{t}-1$. 
Table 5. Effect of low wage subsidy on job-leaving rates (DDD estimates)

\begin{tabular}{lcc|cc}
\hline & \multicolumn{2}{c|}{ Industrial sector } & \multicolumn{2}{c}{ Service sector } \\
\hline Specification I & $(1)$ & $(2)$ & $(3)$ & $(4)$ \\
Treat*after & -0.004 & -0.002 & 0.003 & 0.001 \\
& $(0.008)$ & $(0.008)$ & $(0.008)$ & $(0.008)$ \\
Controls & & $\mathrm{X}$ & & $\mathrm{X}$ \\
Observations & 243364 & 243364 & 187493 & 187493 \\
R-squared & 0.00 & 0.03 & 0.02 & 0.02 \\
\hline Specification II & $(1)$ & $(2)$ & & \\
Amount of subsidy/100 & 0.003 & 0.004 & 0.005 & 0.004 \\
& $(0.006)$ & $(0.006)$ & $(0.005)$ & $(0.005)$ \\
Controls & & $\mathrm{X}$ & & $\mathrm{X}$ \\
Observations & 243364 & 243364 & 187493 & 187493 \\
R-squared & 0.01 & 0.04 & 0.04 & 0.04 \\
\hline
\end{tabular}

Dependent variable: worker exits firm between t-1 and t. The sample consists of workers who were 45-59 years old whose earnings were between 900 and 3000 euros in year $t-1$. The upper panel reports the coefficient on the third level interaction (older*low-wage*after) of equation (2). In all columns other controls are dummies for older, low-wage, (older*low-wage), after and (older*after) and (low-wage*after) interactions. The additional controls for industrial sector (column 2) include educational category (4), gender, union contract, and two-digit industry and for service sector (column 4) gender, educational category and educational field. The lower panel reports the coefficient of amount of subsidy (in 100 euros). In all columns the controls include age dummies, wage group dummies (by 100 euros), wageg*after, ageg*after, and ageg*wageg interactions. Columns 2 and 4 include also additional controls reported above. Standard errors in parentheses.* significant at 5\%; ** significant at $1 \%$. 
Table 6. Effect of low-wage subsidy on working hours for stayers (DDD estimates)

\begin{tabular}{lcc|cc}
\hline & \multicolumn{2}{c|}{ Industrial sector } & \multicolumn{2}{c}{ Service sector } \\
\hline Specification I & $(1)$ & $(2)$ & $(3)$ & $(4)$ \\
Treat*after & 0.045 & 0.046 & 0.002 & 0.001 \\
& $(0.005)^{* *}$ & $(0.005)^{* *}$ & $(0.002)$ & $(0.002)$ \\
Controls & & $\mathrm{X}$ & & $\mathrm{X}$ \\
Observations & 196112 & 196112 & 151078 & 151078 \\
R-squared & 0.11 & 0.15 & 0.03 & 0.05 \\
\hline Specification II & $(1)$ & $(2)$ & $(3)$ & $(4)$ \\
Amount of subsidy & 0.018 & 0.016 & 0.000 & 0.000 \\
& $(0.004)^{* *}$ & $(0.004)^{* *}$ & $(0.001)$ & $(0.001)$ \\
Controls & & $\mathrm{X}$ & & \\
Observations & 196112 & 196112 & 151078 & 151078 \\
R-squared & 0.33 & 0.35 & 0.10 & 0.11 \\
\hline
\end{tabular}

Dependent variable: log. weekly working hours at t. The sample consists of workers who were $45-59$ years old whose earnings were between 900 and 3000 euros in year t-1 and who remained with their employer until the end of year t. The upper panel reports the coefficient on the third level interaction (older*low-wage*after) of equation (3). In all columns controls include dummies for older, low-wage, (older*low-wage), after and (older*after) and (low-wage*after) interactions. The additional controls for industrial sector (column 2) include educational category (4), gender, union contract, and two-digit industry and for service sector (column 4) gender, educational category and educational field. The lower panel reports the coefficient of amount of subsidy (in 100 euros). In all columns the controls include age dummies, wage group dummies (by 100 euros), wageg*after, ageg*after, and ageg*wageg interactions. Columns 2 and 4 include also additional controls reported above. Standard errors in parentheses.* significant at 5\%; ** significant at $1 \%$. 
Table 7. Effect of low-wage subsidy on hourly wages for stayers (DDD estimates)

\begin{tabular}{lcc|cc}
\hline & \multicolumn{2}{c|}{ Industrial sector } & \multicolumn{2}{c}{ Service sector } \\
\hline Specification I & $(1)$ & $(2)$ & $(3)$ & $(4)$ \\
Treat*after & -0.019 & -0.012 & -0.004 & -0.003 \\
& $(0.003)^{* *}$ & $(0.003)^{* *}$ & $(0.003)$ & $(0.003)$ \\
Controls & & $\mathrm{X}$ & & $\mathrm{X}$ \\
Observations & 196112 & 196112 & 151078 & 151078 \\
R-squared & 0.38 & 0.48 & 0.55 & 0.57 \\
\hline Specification II & $(1)$ & $(2)$ & $(3)$ & $(4)$ \\
Amount of subsidy & -0.019 & -0.016 & -0.003 & -0.003 \\
& $(0.003)^{* *}$ & $(0.002)^{* *}$ & $(0.001)^{* *}$ & $(0.001)^{*}$ \\
Controls & & $\mathrm{X}$ & & $\mathrm{X}$ \\
Observations & 196112 & 196112 & 151078 & 151078 \\
R-squared & 0.63 & 0.66 & 0.76 & 0.77 \\
\hline
\end{tabular}

Dependent variable: hourly wage at t. The sample consists of workers who were 45-59 years old whose earnings were between 900 and 3000 euros in year $t-1$ and who remained with their employer until the end of year $t$. The upper panel reports the coefficient on the third level interaction (older*low-wage*after) of equation (3). In all columns controls include dummies for older, low-wage, (older*low-wage), after and (older*after) and (lowwage*after) interactions. The additional controls for industrial sector (column 2) include educational category (4), gender, union contract, and two-digit industry and for service sector (column 4) gender, educational category and educational field. The lower panel reports the coefficient of amount of subsidy (in 100 euros). In all columns the controls include age dummies, wage group dummies (by 100 euros), wageg*after, ageg*after, and ageg*wageg interactions. Columns 2 and 4 include also additional controls reported above. Standard errors in parentheses.* significant at $5 \%$; ** significant at $1 \%$. 
Table 8. Instrumental variables estimates on the effect of actually receiving the subsidy on working hours for stayers

\begin{tabular}{lcccc}
\hline & \multicolumn{2}{c}{ Industrial sector } & \multicolumn{2}{c}{ Service sector } \\
\hline Specification I & $(1)$ & $(2)$ & $(3)$ & $(4)$ \\
\hline person received & 0.111 & 0.113 & 0.003 & 0.002 \\
subsidy & & & & \\
& $(0.012)^{* *}$ & $(0.012)^{* *}$ & $(0.003)$ & $(0.003)$ \\
Controls & & $\mathrm{X}$ & 151078 & 151078 \\
Observations & 196112 & 196112 & 0.03 & 0.05 \\
R-squared & 0.11 & 0.16 & 0.003 & 0.002 \\
\hline Specification II & $(1)$ & $(2)$ & $(3)$ & $(4)$ \\
\hline the amount of the & 0.035 & 0.032 & 0.001 & 0.000 \\
subsidy received & & & & \\
/100 & & & & $(0.002)$ \\
& $(0.007)^{* *}$ & $(0.007)^{* *}$ & 151078 & 151078 \\
Controls & & $\mathrm{X}$ & 0.10 & 0.11 \\
Observations & 196112 & 196112 & 0.001 & 0.000 \\
R-squared & 0.33 & 0.36 & & \\
\hline
\end{tabular}

Dependent variable: log weekly working hours. The sample consists of workers who were 45-59 years old whose earnings were between 900 and 3000 euros in year $\mathrm{t}-1$ and who remained with their employer until t. The upper panel reports the coefficient on actually receiving the subsidy where receiving of subsidy is instrumented by eligibility. In all columns controls include dummies for older, low-wage, (older*low-wage), after and (older*after) and (low-wage*after) interactions. The additional controls for industrial sector (column 2) include educational category (4), gender, union contract, and two-digit industry and for service sector (column 4) gender, educational category and educational field. The lower panel reports the coefficient of the amount of the actual subsidy (in 100 euros), instrumented by the amount of the subsidy the person is eligible for (in 100 euros). In all columns the controls include age dummies, wage group dummies (by 100 euros), wageg*after, ageg*after, and ageg*wageg interactions. Columns 2 and 4 include also additional controls reported above. Standard errors in parentheses.* significant at 5\%; ** significant at $1 \%$. First stage coefficient for columns (1) and (2) in spec I: are $0.407(0.006)^{* *}, 0.405(0.006)^{* *}$ in spec II: The (3) and (4) in spec I: $0.569(0.003)^{* * *}$ and spec. II 0.564 $(0.003)^{* *}$. 